\title{
Share repurchases: Which number of shares should be used by JSE-listed companies when publishing market capitalisation in annual reports?
}

\author{
P.G. Bester and W.D. Hamman* \\ University of Stellenbosch Business School, \\ PO Box 610, Bellville 7535, Republic of South Africa \\ wdh@usb.ac.za \\ L.M. Brummer \\ McGregor BFA, PO Box 786466, Sandton 2146, \\ Republic of South Africa \\ leon.brummer@fin24.com \\ N. Wesson and B.W. Steyn-Bruwer \\ Department of Accountancy, University of Stellenbosch, \\ Private Bag X1, Matieland 7602, Republic of South Africa \\ nwesson@telkomsa net
}

Received October 2008

\begin{abstract}
The legalisation of share repurchases in South Africa since July 1999 introduced additional complexity to financial reporting. The repurchasing of shares by subsidiaries or share trusts has led to a new concept: the number of company shares differs from the number of group shares. Ratios like earnings per share and headline earnings per share are governed by accounting standards and circulars, and prescribe the use of the (weighted) number of group shares. No guidance exists on the calculation of market capitalisation.

This article aims to determine the methods used by companies listed on the JSE Securities Exchange South Africa (JSE) to calculate their number of shares when publishing market capitalisation. It was found that only about $25 \%$ of companies participating in share repurchases and publishing market capitalisation in their annual reports calculated market capitalisation based on the number of group shares. About $75 \%$ of the companies did not calculate their market capitalisation based on the number of group shares (i.e. they omitted to deduct subsidiary repurchases and/or trust consolidations in their calculation of the number of shares). It was also found that the JSE, when compiling the Top 40 index, calculates market capitalisation based on the number of company shares (i.e. ignoring subsidiary repurchases and trust consolidations). Accounting guidance is needed on the reporting of market capitalisation to ensure that this aspect is not overstated by the reporting entities
\end{abstract}

*To whom all correspondence should be addressed.

\section{Introduction}

The rule prohibiting a company from repurchasing its own shares was for many years one of the cornerstones of the principle of maintaining share capital in South Africa (Loubser, 2000: 5). Since 1 July 1999, following the implementation of the Companies Amendment Act 37 of 1999 on 30 June 1999, South African companies have been allowed to acquire their own shares. By allowing companies to repurchase their own shares, the Amendment Act effectively abolished the capital maintenance rule (Delport, 2001: 121). The Act not only allows companies to acquire their own shares, but also the shares of their holding companies (Bhana, 2006: 232). The accounting term, "treasury shares", is used to describe shares repurchased by the company, as well as shares held in the holding company via subsidiaries (SAICA, 2007: IAS 32). (In the South
African context, treasury shares refer only to the latter, as shares repurchased by the company are cancelled from issued share capital in terms of South African legislation. South African accounting standards are however adopted from the International Accounting Standards Board, situated in the United Kingdom (UK), where the legislation on share repurchases differs.)

These recent amendments to the Companies Act introduced various new (legal) challenges (Luiz, 2000: 13). The fact that South African legislation differs from that in the United States of America (USA) and UK, in that South African companies are forced to cancel the shares they repurchase from their issued share capital (Cassim, 2003: 144-145, 151), presents South African companies with a unique challenge - without the overseas precedent to follow, the implications may be underestimated. 
From the accounting perspective, similar new challenges have arisen. Company accountants and auditors were confronted with the new concept of share repurchases and the problem of how to reflect repurchase of shares in financial reports. In practice, a repurchase (or buyback) of a company's own shares is quite simple. When a company buys back its own shares, such shares are cancelled from issued share capital (RSA, 1999: section 85(8)). The reduction in the number of issued shares will be accompanied by a decrease in share capital (and reserves, if applicable), as well as a decrease in cash (SAICA, 2007: IAS 32 par.33). However, if shares are bought by a subsidiary company or a consolidated share trust, such shares are not cancelled, but regarded as treasury shares in the consolidated financial statements. Upon consolidation of company accounts, such treasury shares should then be deducted from equity (share capital and reserves, if applicable) (SAICA, 2007: IAS 32 par. 33).

The effect of a buyback on the number of shares can be illustrated by way of the following example. Suppose that the number of shares issued by the company were 100, and six shares are repurchased by the company. The six shares will be cancelled and the closing number of shares of the company (and the group) will be 94. Suppose, however, that a further five shares were bought by a subsidiary of the company and are therefore not cancelled, but kept as treasury shares. Upon consolidation, the closing number of shares of the company remains at 94 , but the closing number of shares of the group becomes 89. A new concept has therefore arisen since 1999: the number of company shares may differ from the number of group shares, which prompts the question: Which number of shares must be used when calculating financial ratios like earnings per share (EPS), headline earnings per share (HEPS), net asset value per share (NAV) and market capitalisation?

In the case of EPS (and HEPS) it is to be expected that companies will prefer to use the number of shares of the group (89 in the example above) as a basis to determine the weighted average number of shares. The EPS calculation uses the number of shares as a denominator - and the smaller the denominator, ceteris paribus, the larger the EPS. Using the group closing number of shares as a basis for calculating EPS is appropriate from a consolidation point of view and it is in line with the requirements of the accounting standard on EPS (SAICA, 2007: IAS 33) and the accounting circular on HEPS (SAICA, 2007: CC 07/02). (CC 07/02 was replaced by CC 09/07 from 1 October 2007. The data included in this article relate to periods prior to 1 October 2007.)

From a market capitalisation perspective, companies may choose to use the larger number of shares as reflected by the company's closing number (94 in the example above), because it will result in larger market capitalisation. Market capitalisation is a reflection of a company's size and many stock market indexes, such as the JSE Top 40 and other market capitalisation-based indexes, are compiled on a basis of market capitalisation. There may therefore be an incentive for companies to state a high market capitalisation in order to qualify for more prestigious indexes.
When companies report their financial results, EPS and HEPS are calculated according to rigorous standards and verified by auditors. The auditors, however, are not called upon to report on the accuracy of market capitalisation, which usually forms part of the statistical review or multiyear review of the annual published report. The auditors only need to determine that the information contained in these statistical reviews does not include material inconsistencies or material misstatements of fact (SAICA, 2004: ISA 720). There is no accounting standard dealing with the calculation of market capitalisation - which leaves the calculation of market capitalisation to the discretion of the company. This usually results in the company using a different (larger) number of shares for market capitalisation than the number of shares used for other mandatory financial ratios. Furthermore, entities hardly ever define the calculation of market capitalisation in their annual reports.

The authors of this article are of the opinion that, where accounts are consolidated, the consolidation concepts must be applied on a consistent basis. This means that the number of shares of the group (89 in the example above) should be used in the cases where EPS and market capitalisation are calculated.

\section{Research problem and objectives}

The aim of this article is to determine which methods are being used by JSE-listed companies involved in share repurchase activities to calculate their published market capitalisation. More specifically, the purpose is to determine whether companies use the closing number of shares of the company or the closing number of shares of the group in the calculation of the market capitalisation of the group. This article will therefore concentrate only on quantifying the number of shares held by the company and the group when publishing market capitalisation.

A further intention is to establish whether companies are conforming to accepted standards for reporting market capitalisation. To form an opinion on this issue, the regulatory environment governing share repurchases and the consolidation of company accounts is reviewed in detail.

Finally, as share repurchasing is still a relatively new concept in South Africa, the article aims to contribute to the general understanding and knowledge base of local share repurchase mechanisms. A primary objective is to compile a database of companies participating in share repurchases, from which further studies can be conducted.

The following issues will be explored in future research and are therefore not addressed in this article:

- The debate on whether the Companies Amendment Act is adequate.

- $\quad$ The debt/equity ratio implication of share repurchases.

- The short- and long-term market reaction to share repurchases, including buy-and-hold simulation. 
- Economic reasons for share repurchases, including, among others, net asset value per share compared to share price, to establish over- and under-priced companies.

- A $100 \%$ comparison between the number of shares included in the shareholder analysis (shareholder spread) and the number of shares disclosed in the share capital note in the annual report of the reporting entity.

- Whether the published market capitalisation has any implication on the quoted share price.

\section{Share repurchase regulatory environment in South Africa}

The repurchase of shares is governed by various legislation and statutory requirements contained in the Companies Act, the Companies Amendment Act and the JSE Listing Requirements. Furthermore, share repurchases by the company are deemed to be dividends and therefore the Income Tax Act, specifically sections on Secondary Tax on Companies (STC), is applicable. When shares are repurchased by subsidiaries or share incentive trusts, the consolidation of company accounts is required, as specified by the relevant accounting standards.

\section{South African Companies Act}

The Companies Act, Act 61 of 1973 (RSA, 1973), was amended through the Companies Amendment Act, Act 37 of 1999 (RSA, 1999), to allow companies to buy back their own shares. The provisions governing share repurchases are contained in Section 39 of the Companies Act, as well as Sections 85 to 90 of the Companies Amendment Act. The relevant provisions of the Act are summarised as follows:

- A company, if authorised by its articles, may, by a special resolution of the company, acquire its own shares [Section 85(1)].

- The approval by resolution may either be for repurchase under a general or a specific authority. If the approval is for a general repurchase, it will only be valid until the next annual general meeting [Section 85(3)].

- $\quad$ Shares issued by a company and subsequently acquired will be cancelled as issued shares and restored to the status of authorised shares [Section 85(8)].

- $\quad$ Section 89 allows subsidiary companies (in total) to acquire shares in their holding company to a maximum of $10 \%$ of the issued share capital of the holding company.

- $\quad$ Shares in the company may not be repurchased under Section 85 if, following such acquisition, there would no longer be any shares in issue other than convertible or redeemable shares.
- $\quad$ Listed companies are further compelled to comply with additional conditions as determined by the relevant stock exchange [Section 87(5)].

\section{JSE listing requirements}

Section 5, paragraphs 5.67-5.84, of the JSE Listing Requirements (JSE, 2007) impose additional requirements and provisions for share repurchases. The Listing Requirements distinguish further between a repurchase under general authority (general repurchase) and a repurchase under specific authority (specific repurchase). Essentially, a general repurchase is equivalent in style to that of an American (USA) open-market share repurchase (Daly, 2002: 13), while the specific repurchase is similar to a fixed-price USA-style tender offer.

\section{General repurchases}

A general repurchase is a repurchase conducted on the open market through the JSE without prior understanding between the company and the counterparts. The repurchase may not exceed $20 \%$ of the company's share capital in any one financial year [Section 5.68]. Repurchases may not be made at a price greater than $10 \%$ above the weighted average of the market value for the five business days immediately preceding the repurchase [Section 5.72(d)]. All open market share repurchases must be channelled through a single broker [Section 5.72(e)]. Once a company has repurchased 3\%, or any 3\% increment thereafter, of its own securities, the company is obliged to announce such repurchases by no later than 08:30 on the following business day. These announcements must be distributed through the Securities News Agency (SENS) [Section 5.79]. SENS is the official electronic forum through which companies disseminate related information.

\section{Specific repurchases}

A specific repurchase is a commitment to repurchase a specified number of shares at a fixed price. Specific repurchases may be executed in two ways. The specific offer may be extended to one or more specifically named shareholders or the offer may be open to all shareholders pro rata to their shareholding. A pro rata offer must remain open for 21 days. Any announcement of a specific offer must be pursued by the company, unless permission is obtained from the JSE not to do so [Section 5.69(h)].

\section{Additional provisions}

In both the cases of general and specific repurchases, the company directors must provide a statement that the solvency and the liquidity position will be adequate for the 12 months subsequent to the date of approval of the buyback [Sections 11.23 to 11.27].

\section{South African Income Tax Act}

STC was introduced in South Africa in 1993. STC payment is governed by Sections $64 \mathrm{~B}$ and 64C, together with the definition of "dividend" in section 1 of the Income Tax Act 
58 of 1962 (RSA, 1962). STC is levied on the dividend paid by the company at a rate of $12,5 \%$ (in respect of the periods covered in this study, i.e. 1999 till 2006). Repurchases by the holding company of its own shares will be regarded as a dividend to the extent that it represents a distribution to shareholders. The amount of the dividend in a repurchase is the amount with which the profits attributable to shareholders were reduced. The nominal value of the shares repurchased, as well as all debits allocated to the share premium account [Section 76(d) of the Companies Act], is therefore not regarded as a dividend [Section 1 of the Income Tax Act].

On the other hand, repurchases of shares by a subsidiary of a holding company will not be regarded as a dividend and will therefore not be subject to STC. This is one of the main reasons why companies go to the trouble of buying back shares through a subsidiary rather than repurchasing shares directly. Subsidiaries are allowed to hold a maximum of only $10 \%$ of the holding company's issued shares as treasury shares. Companies occasionally repurchase treasury shares from their subsidiaries in order to allow the subsidiaries to continue STC-free share repurchases. Werksmans Attorneys (2004) warn that repurchasing treasury shares from subsidiaries may create tax problems for the holding company, with the original repurchases becoming taxable in the company's hands under certain circumstances.

It is therefore obvious that repurchases of shares in South Africa are affected by the income tax treatment thereof, requiring a distinction between repurchases of its own shares by the holding company and repurchases by its subsidiary company. However, this may become of academic value in the future as proposed amendments to STC legislation intend to replace STC payment by companies with a withholding tax system (the implementation date of the amendment has not yet been promulgated). It is also not yet clear whether share repurchases will attract the same tax as dividends when the STC is migrated to a withholding tax.

\section{Consolidation of company share trusts}

While the consolidation of subsidiary accounts has been a standard practice, uncertainty has existed regarding the accounting treatment of company share trusts prior to 2004. The central question was whether companies control their related share trusts in the manner contemplated by the Standard of Generally Accepted Accounting Practice (SAICA, 2007: IAS 27) Consolidated and Separate Financial Statements. If a company controls its share trust, the share trust should be consolidated - thus affecting the group financial statements and the reported EPS.

In February 2004, following a recommendation by the GAAP Monitoring Panel (SAICA, GAAP Monitoring Panel, 2004), the JSE announced that all listed companies, for annual periods ending on or after 31 March 2004, were required to consolidate their share trusts (JSE, 2004). Although many companies did not consolidate their share trusts prior to 2004, it was contended that, although accounting standards did not specifically address this issue, the application of the principles of IAS 27 should generally lead to the consolidation of share trusts (Wainer, 2004). The accounting interpretation dealing with special purpose entities, SIC-12 Consolidation - Special Purpose Entities (SAICA, 2007), previously excluded equity compensation plans, but it was amended to include these plans for annual periods beginning on or after 1 January 2005. Consolidation of share trusts, qualifying as special purpose entities, is therefore required for all companies (listed or non-listed) for annual periods beginning on or after 1 January 2005.

It is therefore concluded that, as of 2004, the group's number of shares (reduced by the number of shares held by the trust) must be used as the denominator in calculating EPS. There is no conclusive guideline whether the same applies to the calculation of market capitalisation.

\section{Data collection}

The data required for analysing the calculation of reported market capitalisation include the annual movement in the number of issued company shares and the number of shares held by subsidiaries and share trusts (treasury shares), as well as the closing share price and published market capitalisation at financial year-end. While accurate data for the number of issued company shares and the year-end closing share price are available from financial databases like McGregor BFA, Reuters, or INET-Bridge, no reliable data are available on shares held by subsidiaries and share trusts as a result of share repurchase activities. This lack of readily available information on share repurchase activity in South Africa required data to be collected from scratch to calculate the number of group shares.

Data collection in South Africa was given a jump-start by empirical repurchase data collected by Daly (2002). Daly analysed the share returns of JSE-listed companies that made 88 announcements of open-market share repurchases under a general authority between 1 July 1999 and 30 September 2001. Data listed in his report included names of companies, dates of SENS announcements and values of the repurchases, as well as whether the repurchases were made by the company or the subsidiary. Bhana (2007) published the first scientific article in South Africa on the same topic. His research covered the period October 2000 to March 2003 and his sample comprised 117 repurchase announcements, but (unlike Daly's research) specific details of the repurchase announcements were not listed in his article.

Four methods could be used to obtain repurchase information. The first method was to record SENS announcements of companies' intentions to conduct repurchases. This is a quick way to find an indication of repurchase activity, because announcements can be searched electronically through the SENS database. Information regarding specific repurchases searched in this manner is quite reliable because these offers usually result in actual repurchases when accepted by shareholders. However, announcements of intentions to repurchase via general authority holds little resemblance to actual repurchases, owing to the fact that a general offer does not constitute a 
binding commitment. In fact, most companies currently obtain general authority to repurchase shares on an annual basis, even if they have no specific intention of repurchasing shares. It merely opens the door for opportunistic share repurchases in times of high share price fluctuations.

A second, additional method was therefore considered, namely where all the incremental 3\% general repurchase SENS announcements would be collected to obtain data on actual general share repurchases. An obvious limitation of this approach is that some companies may have carried out general share repurchases over a specific period, but fail to cross the 3\% threshold and therefore no announcement in that specific period is made. This method therefore does not present a complete picture of share repurchases in South Africa over a specific time period. A further limitation is that the SENS announcement does not cover the unusual activities such as the consolidation of share trusts after 2004, issue of shares directly to share trusts, or the sale of treasury shares.

While the first two methods provided realistic overall data for specific and general actual repurchases, they still did not provide sufficiently accurate data of subsidiary and share trust shareholding in order to calculate market capitalisation at a specific point in time. The third and significantly more labour-intensive method adopted was to determine the actual shares repurchased by analysing all the annual reports from 1999 to 2007 and noting changes in the number of shares issued. The directors' report, share capital note to the balance sheet and shareholder analysis (shareholder spread) of annual reports were scanned carefully for changes in treasury shares held by subsidiaries or share trusts. Although this method proved to be immensely time-consuming, the authors were able to identify repurchases by the company (that were cancelled), repurchases and sales by subsidiaries (and not cancelled but regarded as treasury shares and consolidated), as well as details of consolidated share trusts.

As a final verification, the data from all three methods were combined to confirm that no repurchase activities had been omitted. This also served to give an indication of the proportion of total actual repurchases covered by the $3 \%$ SENS announcements.

Method three was used in this study to determine the group closing balances of shares. All the data requirements for method three were obtained from the published annual reports of the companies (hard copies) and, failing this, downloaded from either the annual reports from the Internet or McGregor BFA (product called Library).

\section{Sample selection}

The University of Stellenbosch Business School (USB) compiled a database covering repurchase activities based on actual changes in the number of issued shares. Only share repurchases of ordinary shares and listed $\mathrm{N}$-shares were included in the database. The sectors covered by the USB database exclude Mining, Financials, Development Capital and Alternative Exchange. Although this database covers all repurchases from 1999 to 2007, only data for the most complete recent calendar year (2006) for which all published annual reports are available will be used in this article. The year 2006, in this context, refers to the company’s financial year ending in 2006.

Companies were included in the sample for this article based on the following selection criteria:

- $\quad$ Must be JSE-listed in the sectors included in the USB database, as defined above.

- Must have published a 2006 annual report (KAP International, for instance, was excluded because it changed its year-end to June in December 2005 and therefore had no 2006 annual report in the ensuing 18month period ending June 2007).

- $\quad$ Must have published market capitalisation in its 2006 annual report (Shoprite Holdings, for instance, was excluded because it did not publish market capitalisation in any period from 1999 to 2007, while Dorbyl stopped publishing market capitalisation in 2005 and were thus also excluded).

- $\quad$ Must have been involved in share repurchase activity or consolidation of share trusts between 1999 and 2007.

\section{Research methodology}

The USB share repurchase database distinguishes between shares repurchased by the company (and thus cancelled), shares repurchased in the holding company by subsidiaries (not cancelled, but consolidated) and shares held by trusts (over which the company exercises control, and which are not cancelled, but consolidated). The number of shares held by each entity can thus be determined by reconciling the repurchases of the shares together with any shares issued or sold for the period 1999 to 2007.

The effective number of shares held by the group is obtained from the following equation: number of shares of the group $=$ the number of shares held by the company (after deduction of cancellations), less the number of shares held by the subsidiaries, less the consolidated number of shares held by the trusts. The number of group shares was obtained from the number of shares as disclosed in the share capital note, statement of changes in equity and directors' report of the reporting entity. Although the shareholders analysis (shareholder spread) was used as confirmation, no adjustments were made to the number of shares if it did not correspond to the information included in the share capital note, statement of changes in equity and directors' report of the reporting entity. Furthermore, it may not be entirely obvious from annual reports whether a company has control over its share trusts and whether the trust needs to be consolidated. All companies listing their share trusts in the shareholder analysis of the annual report generally need to consolidate these trusts. However, if share trust consolidation is not mentioned explicitly in the annual report, it is assumed that the company (and hence its auditors) does not require share trust consolidation. 
It is noted at this stage that the number of shares of the group will remain unaffected if the holding company buys shares previously repurchased by a subsidiary from that subsidiary and then cancels such shares. While the number of shares of the group remains unaffected, the number of shares of the company will decrease.

The research problem is, in essence, to determine which number of shares South African companies use to calculate their market capitalisation. There are three potential options that companies may choose: use the number of shares of the company (i.e. ignore any shares held by subsidiaries or share trusts), use the consolidated number of shares of the company and only subsidiaries (i.e. still ignore any shares held by share trusts), or use the fully consolidated group number of shares (i.e. take both subsidiary and share trust holding into account). Technically it is possible that companies may use the number of company shares consolidated with only share trusts (i.e. ignore subsidiary shares), but it is highly unlikely that they would do so.

The published market capitalisation is compared to four calculated market capitalisations, using number of issued shares for the company, company shares consolidated with subsidiary shares only, company shares consolidated with share trusts only, and fully consolidated group shares respectively, to determine which method is used by each company.

\section{Results}

The completed database of companies involved in share repurchases or consolidation of share trusts for the period 1999 to 2007 contained 129 companies after excluding companies de-listed or suspended before they published a 2006 annual report. The authors decided to report on the cumulative share repurchase results up to the 2006 financial year-end and the published market capitalisation as reported in the 2006 annual reports. Of the 129 companies in the database, only 63 companies published market capitalisation in their 2006 annual reports. The published market capitalisations of these 63 companies were compared to calculated market capitalisations based on number of group shares. The results are summarised in Table 1.

\section{Table 1. Summary of companies publishing market capitalisation in 2006 annual reports}

\begin{tabular}{|c|c|c|}
\hline $\begin{array}{l}\text { Explanation of codes of different methods followed by companies in the calculation of the } \\
\text { number of shares used }\end{array}$ & $\begin{array}{l}\text { Number of } \\
\text { companies }\end{array}$ & $\%$ \\
\hline Market capitalisation based on number of group shares: & 16 & $25,4 \%$ \\
\hline 1 = Companies without cumulative treasury shares to consolidate & 5 & $8 \%$ \\
\hline $\begin{array}{l}2=\text { Companies which consolidated cumulative share repurchases by subsidiaries but had no } \\
\text { consolidated share trusts }\end{array}$ & 4 & $6,3 \%$ \\
\hline 3 = Companies with no cumulative subsidiary repurchases, but consolidated cumulative share trusts & 4 & $6,3 \%$ \\
\hline $\begin{array}{l}4=\text { Companies which consolidated cumulative share repurchases by subsidiaries as well as share } \\
\text { trusts }\end{array}$ & 3 & $4,8 \%$ \\
\hline Market capitalisation not based on number of group shares: & 47 & $74,6 \%$ \\
\hline $\begin{array}{l}5=\text { Companies which ignored the cumulative repurchases of subsidiaries but had no consolidated } \\
\text { trusts }\end{array}$ & 14 & $22,2 \%$ \\
\hline $\begin{array}{l}6=\text { Companies which had no cumulative share repurchases by subsidiaries and ignored the } \\
\text { consolidation of share trusts }\end{array}$ & 11 & $17,4 \%$ \\
\hline $\begin{array}{l}7=\text { Companies which ignored the cumulative repurchases of subsidiaries as well as the } \\
\text { consolidation of share trusts }\end{array}$ & 17 & $27 \%$ \\
\hline $\begin{array}{l}8=\text { Companies which consolidated the cumulative repurchases of subsidiaries, but ignored the } \\
\text { cumulative consolidation of share trusts }\end{array}$ & 3 & $4,8 \%$ \\
\hline $9=$ Undetermined error & 2 & $3,2 \%$ \\
\hline Total number of companies publishing market capitalisation in the 2006 annual reports & 63 & $100 \%$ \\
\hline
\end{tabular}

Only 16 companies (25,4\%) published the market capitalisation based on the correct number of group shares as listed in Table 2. Of these 16 companies, five companies held no cumulative repurchased shares through subsidiaries or share trusts at their respective 2006 year-ends. The other 11 companies published the market capitalisation by using the group number of shares after consolidating shares held by subsidiaries or trusts.

More than $74 \%$ of the companies (47) did not publish market capitalisation based on the number of group shares. There were 14 companies that overstated their market capitalisation by using closing balances of the company and ignoring repurchases of subsidiaries (no shares held by trust). A further 11 companies ignored shares held by trusts (no repurchases by subsidiaries), and 17 companies ignored shares held by both subsidiaries and share trusts. Three companies actually took repurchases by subsidiaries into account, but ignored the trust consolidation. Lastly, two companies (Sappi and Steinhoff) published market capitalisations which could not be reconciled to any particular number of shares. Astral Foods published a market capitalisation of R3 827 million in 2006, which was modified to R3 743 million in the 2007 annual report. The 2007 figure is based on the number of company shares. 
Table 2. Companies publishing market capitalisation based on number of group shares in 2006 annual reports

\begin{tabular}{|c|c|c|c|c|c|c|}
\hline \multirow{2}{*}{\multicolumn{2}{|c|}{ Company }} & \multirow{4}{*}{\multicolumn{2}{|c|}{\begin{tabular}{cc}
\multicolumn{2}{c}{ Market capitalisation } \\
$\begin{array}{c}\text { Published by } \\
\text { company }\end{array}$ & $\begin{array}{c}\text { Calculated by } \\
\text { authors }\end{array}$ \\
R million & R million \\
25993.0 & 25992.7
\end{tabular}}} & \multirow{3}{*}{\multicolumn{2}{|c|}{\begin{tabular}{cc|}
\multicolumn{2}{c|}{ Treasury shares } \\
(Subsidiary shares $x$ & (Trust shares $x$ 100) $/$ \\
100) / company & company shares \\
shares & \\
$\%$ & $\%$ \\
\end{tabular}}} & \multirow{4}{*}{\begin{tabular}{|c} 
Code \\
see Table 1
\end{tabular}} \\
\hline & & & & & & \\
\hline & & & & & & \\
\hline 1 & Barloworld & & & & & \\
\hline 2 & Enaleni Pharmaceuticals & 1794,1 & 1794,1 & & $1,7 \%$ & 3 \\
\hline 3 & Excellerate Holdings & 102,7 & 102,7 & $5,8 \%$ & & 2 \\
\hline 4 & Hudaco Industries & 1620,0 & 1619,6 & $7,7 \%$ & & 2 \\
\hline 5 & Italtile & 3391,0 & 3400,2 & & $3,1 \%$ & 3 \\
\hline 6 & Labat Africa & 33,6 & 33,6 & & & 1 \\
\hline 7 & Mittal Steel South Africa & 43795,0 & 43795,1 & & & 1 \\
\hline 8 & MTN Group & 158681,0 & 158680,9 & & & 1 \\
\hline 9 & New Clicks Holdings & 3597,8 & 3597,8 & $1,4 \%$ & $0,8 \%$ & 4 \\
\hline 10 & Nictus & 26,7 & 26,7 & & & 1 \\
\hline 11 & Omnia Holdings & 1923,0 & 1923,1 & & $3,5 \%$ & 3 \\
\hline 12 & Primeserv Group & 42,3 & 42,3 & $8,1 \%$ & $5,3 \%$ & 4 \\
\hline 13 & Reunert & 12012,0 & 12012,5 & $9,8 \%$ & & 2 \\
\hline 14 & The Bidvest Group & 29541,0 & 29541,0 & $8,0 \%$ & & 2 \\
\hline 15 & The Spar Group & 6078,0 & 6077,5 & & $1,6 \%$ & 3 \\
\hline 16 & Tiger Brands & 22 157,0 & 22157,0 & $5,0 \%$ & $3,4 \%$ & 4 \\
\hline
\end{tabular}

In Table 3 the market capitalisation as published by the company (column a) and the market capitalisation as calculated by the authors (column b) is provided for the companies that published market capitalisation not based on the number of group shares. The percentage of market capitalisation overstatement (column c), expressed as a percentage of the market capitalisation based on the number of group shares (column b), is also provided, together with the percentage shares held by subsidiaries (column d) and share trusts (column e) relating to the overstatement. The overstated market capitalisation (column c) does not however match the total of the subsidiary (column d) and share trust (column e) shareholding, because the latter (column $\mathrm{d}$ and e) is expressed as a percentage of the number of company shares rather than number of group shares.

\section{Discussion of results}

No examples of errors were found in the case where the company repurchased shares and cancelled these shares. However, it is clear from the results above that the majority of companies $(>74 \%)$ overstate their market capitalisation by neglecting to consolidate treasury shares held by subsidiaries and/or share trust. While the overstatement by some companies, like Gijima AST Group, is very small and hardly relevant, on average the overstatement is $8,8 \%$. The maximum overstatement by Netcare was 50,4\%. At least some companies like Aspen Pharmacare, Cashbuild,
Nampak, Sasol and Super Group acknowledge that they were not using closing balances of the group to calculate market capitalisation.

It would appear that the problem in calculating market capitalisation is the result of companies overlooking the fact that there are two different balances of shares in issue. The term "shares in issue" is used interchangeably for the two concepts without defining it properly. A few companies, like Shoprite (not included in the sample because it did not publish its market capitalisation), aptly define the concepts: balance of shares of the company and balance of shares of the group. New Clicks and Primeserv not only publish the correct market capitalisation based upon the closing balance of the group (Table 2), but they also publish a market capitalisation based upon the closing balance of the company. On the other hand, Foschini defines both the number of company and group shares, but still neglects to publish market capitalisation based on the number of group shares (Table 3). Remgro publishes a very detailed table covering all the repurchases by the company and subsidiaries as well as the consolidation of share trusts for the previous four years, but it fails to define the concepts: balance of shares of company and group, and thus proceeds to calculate a market capitalisation figure not based on the group number of shares. 
Table 3. Companies publishing market capitalisation not based on number of group shares in 2006 annual reports

\begin{tabular}{|c|c|c|c|c|c|c|}
\hline \multirow{3}{*}{ Company } & \multicolumn{3}{|c|}{ Market capitalisation } & \multicolumn{2}{|c|}{ Treasury shares } & \multirow{3}{*}{$\begin{array}{c}f \\
\text { Code } \\
\text { see } \\
\text { Table } 1\end{array}$} \\
\hline & $\begin{array}{c}\text { a } \\
\text { Published by } \\
\text { company }\end{array}$ & $\begin{array}{c}\text { b } \\
\text { Calculated } \\
\text { by authors }\end{array}$ & $\begin{array}{c}c \\
\text { Overstated }= \\
(a / b-1) x \\
100\end{array}$ & $\begin{array}{c}d \\
\text { (Subsidiary } \\
\text { shares } x \text { 100)/ } \\
\text { company shares }\end{array}$ & $\begin{array}{c}e \\
\text { (Trust shares } x \\
\text { 100)/ } \\
\text { company } \\
\text { shares }\end{array}$ & \\
\hline & $R$ million & $R$ million & $\%$ & $\%$ & $\%$ & \\
\hline 1 AECI & 8240,7 & 7536,9 & $9,3 \%$ & $8,5 \%$ & & 5 \\
\hline 2 Afgri & 2 183,6 & 2024,8 & $7,8 \%$ & & $6,6 \%$ & 8 \\
\hline 3 Argent Industrial & 1162,7 & 1071,9 & $8,5 \%$ & & $7,8 \%$ & 6 \\
\hline 4 Aspen Pharmacare Holdings & 14102,9 & 12681,9 & $11,2 \%$ & $10,1 \%$ & & 5 \\
\hline 5 Astral Foods & 3827,0 & 3 369,1 & $13,6 \%$ & $10,0 \%$ & & 5 \\
\hline 6 Astrapak & 1891,8 & 1669,2 & $13,3 \%$ & $2,8 \%$ & $8,9 \%$ & 7 \\
\hline 7 Aveng & 8497,3 & 8349,1 & $1,8 \%$ & & $1,7 \%$ & 6 \\
\hline 8 AVI & 4362,9 & 4320,4 & $1,0 \%$ & & $1,0 \%$ & 6 \\
\hline 9 Brandcorp Holdings & 688,3 & 659,4 & $4,4 \%$ & $4,2 \%$ & & 5 \\
\hline 10 Cashbuild & 1083,8 & 950,4 & $14,0 \%$ & & $12,3 \%$ & 6 \\
\hline 11 Compu-Clearing Outsourcing & 100,1 & 97,1 & $3,1 \%$ & $3,0 \%$ & & 5 \\
\hline 12 Datatec & 3220,0 & 3204,9 & $0,5 \%$ & $0,5 \%$ & & 5 \\
\hline 13 Distribution and Warehousing Network & 1484,9 & 1375,3 & $8,0 \%$ & $4,4 \%$ & $3,0 \%$ & 7 \\
\hline 14 Distell Group & 7760,0 & 7742,8 & $0,2 \%$ & & $0,2 \%$ & 6 \\
\hline 15 Edgars Consolidated Stores & 21503,0 & 18853,4 & $14,1 \%$ & $9,3 \%$ & $3,1 \%$ & 7 \\
\hline 16 Ellerine Holdings & 8308,0 & 8 108,3 & $2,5 \%$ & $1,8 \%$ & $0,6 \%$ & 7 \\
\hline 17 EnviroServ Holdings & 615,8 & 584,7 & $5,3 \%$ & & $4,6 \%$ & 8 \\
\hline 18 ERP.com Holdings & 252,8 & 224,7 & $12,5 \%$ & $11,1 \%$ & & 5 \\
\hline 19 Foschini & 14011,4 & 12384,4 & $13,1 \%$ & $7,0 \%$ & $4,6 \%$ & 7 \\
\hline 20 Gijima Ast Group & 472,7 & 472,7 & $0,0 \%$ & $0,0 \%$ & $0,0 \%$ & 7 \\
\hline 21 Grindrod (ordinary shares) & 7310,5 & 7007,2 & $4,3 \%$ & $4,1 \%$ & & 5 \\
\hline 22 Group Five & 2867,1 & 2125,1 & $34,9 \%$ & & $25,9 \%$ & 6 \\
\hline 23 Imperial Holdings & 26715,0 & 24112,2 & $10,8 \%$ & $9,7 \%$ & & 5 \\
\hline 24 Lewis Group & 6160,0 & 5856,3 & $5,2 \%$ & $3,4 \%$ & $1,6 \%$ & 7 \\
\hline 25 Massmart Holdings & 8819,7 & 8804,9 & $0,2 \%$ & $0,2 \%$ & & 5 \\
\hline 26 Medi-Clinic Corporation & 8143,1 & 7356,2 & $10,7 \%$ & $0,9 \%$ & $8,8 \%$ & 7 \\
\hline 27 Mr Price Group & 4956,0 & 4949,5 & $0,1 \%$ & & $0,1 \%$ & 6 \\
\hline 28 Nampak & 11898,0 & 10578,5 & $12,5 \%$ & $6,9 \%$ & $4,2 \%$ & 7 \\
\hline 29 Network Healthcare Holdings & 22056,2 & 14662,0 & $50,4 \%$ & $19,1 \%$ & $14,4 \%$ & 7 \\
\hline 30 Oceana Group & 1830,9 & 1603,6 & $14,2 \%$ & & $12,4 \%$ & 6 \\
\hline 31 Pals Holdings & 16,4 & 14,7 & $11,5 \%$ & & $10,3 \%$ & 6 \\
\hline 32 Paracon Holdings & 714,8 & 666,6 & $7,2 \%$ & $6,7 \%$ & & 5 \\
\hline 33 Pick n Pay Stores & 14729,9 & 13946,1 & $5,6 \%$ & $5,3 \%$ & $0,0 \%$ & 7 \\
\hline 34 Remgro & 60588,0 & 59 984,4 & $1,0 \%$ & $0,3 \%$ & $0,7 \%$ & 7 \\
\hline $\begin{array}{l}35 \text { Rex Trueform Clothing Company } \\
\text { (N shares) }\end{array}$ & 110,0 & 106,7 & $3,1 \%$ & & $3,0 \%$ & 6 \\
\hline 36 Sappi & 2928,0 & 2889,6 & $1,3 \%$ & $5,1 \%$ & & 9 \\
\hline 37 Sasol & 187825,0 & 171288,4 & $9,7 \%$ & $8,8 \%$ & & 5 \\
\hline 38 Spur Corporation & 810,4 & 731,7 & $10,8 \%$ & $9,7 \%$ & & 5 \\
\hline 39 Steinhoff International Holdings & 24351,0 & 24369,8 & $-0,1 \%$ & & $0,4 \%$ & 9 \\
\hline 40 Sun International & 9357,0 & 8818,8 & $6,1 \%$ & & $5,5 \%$ & 8 \\
\hline 41 Super Group & 4858,0 & 4258,3 & $14,1 \%$ & $9,6 \%$ & $2,8 \%$ & 7 \\
\hline 42 Tiger Wheels & 1365,0 & 1314,2 & $3,9 \%$ & $3,7 \%$ & & 5 \\
\hline 43 Tourism Investment Corporation & 1370,1 & 1271,4 & $7,8 \%$ & $4,4 \%$ & $2,8 \%$ & 7 \\
\hline 44 Transpaco & 128,1 & 109,5 & $16,9 \%$ & $10,0 \%$ & $4,5 \%$ & 7 \\
\hline 45 Truworths International & 9924,0 & 8916,5 & $11,3 \%$ & $10,1 \%$ & $0,0 \%$ & 7 \\
\hline 46 Winhold & 164,1 & 163,2 & $0,6 \%$ & & $0,6 \%$ & 6 \\
\hline 47 Woolworths Holdings & 12112,0 & 10520,6 & $15,1 \%$ & $9,8 \%$ & $3,3 \%$ & 7 \\
\hline
\end{tabular}


A fact not reflected in the data for a specific year is that the overstated market capitalisation can fluctuate widely from time to time. This occurs when the company repurchases shares, previously repurchased by subsidiaries, from the subsidiaries. Remgro is an example of a company that repurchased treasury shares from its subsidiaries to make way for further repurchases by the subsidiaries, which are only allowed to hold a maximum percentage of $10 \%$ of the shares of the holding company. In 2005, Remgro overstated its market capitalisation by $7,2 \%$. However, after purchasing and cancelling 37691443 shares held by the subsidiaries, the overstatement dropped to only 1,0\% in 2006.

In reference to the maximum $10 \%$ holding by subsidiaries, it is noted that Netcare exceeds this regulation by a significant margin. This situation came about when Netcare increased its shareholding in Netpartner, thereby causing its status to change from an associate to a subsidiary company. The subsequent consolidation resulted in Netcare "inheriting" its own shares held by Netpartner, when calculating its treasury shares. A few other companies, including Aspen, ERP.com and Truworths, also exceed the $10 \%$ limitation by a minor margin. In these cases the breach was caused by additional share repurchases by the company after subsidiaries repurchased close to $10 \%$, which required cancellation of shares in issue and consequently increased the effective shareholding of the subsidiary. According to Butler (1999: 299 ) it is not clear how the $10 \%$ is to be calculated. It is uncertain whether shares cancelled according to Section 85 (relating to the repurchase of company's own shares) should be taken into account.

The complexity highlighted by this article may be a direct result of South Africa's current regulatory environment on share repurchases. This country's regulations differ from those in the USA and UK in one important respect: South African companies are forced to cancel the shares they repurchase from their issued share capital. This encourages companies to repurchase shares through separate entities like subsidiaries and share trusts, thereby complicating the traceability of share repurchases. UK companies have a more flexible arrangement and they may hold repurchased shares as treasury shares, sell them for cash, transfer them to share schemes, or cancel them as per Statutory Instrument 2003 No. 1116 (UK, 2003). This promotes the repurchase of shares by a single entity, the holding company, thereby simplifying the administration of this activity. USA and UK companies therefore need not distinguish between treasury shares purchased by the holding company and those repurchased by subsidiaries and trusts when calculating and presenting their shares in issue of the group.

Although this discussion regarding the correct market capitalisation may seem trivial because it is not an audited financial ratio, the market capitalisation should still reflect a fair overall value of the company. In simple terms, it can be regarded as the amount an investor who wishes to buy the whole company can expect to pay. From this angle, it may be contended that the company is misleading potential investors by publishing an inflated market capitalisation based on the number of company shares rather than the shares held by the group. It is interesting to note that the JSE uses market capitalisation based on the number of company shares to compile its Top 40 index. This became apparent when comparing market capitalisations (on a daily, weekly, monthly and yearly basis) as provided by McGregor BFA (product called Analyser: Module Price Data). These market capitalisations were supplied by the JSE to McGregor BFA. A company like Netcare, currently included in the Top 40, would not qualify for inclusion if the market capitalisation of the group were used as a basis for selection.

\section{Conclusion}

The fact that South African companies were allowed to repurchase their own shares from 1 July 1999 created new challenges for financial analysts, as well as company accountants and auditors. For the financial analysts it introduced an additional complexity during the evaluation of company financial performance. The accuracy of these valuations is very much dependent on the manner in which repurchase activities are reported. The problem facing the company accountant is how to incorporate the new concept of repurchases into financial reporting to calculate the number of group shares to reflect the market capitalisation of the group.

The authors of this article addressed only a small problem facing the company accountant, namely how to determine market capitalisation after 1 July 1999. The problem is actually one of determining the appropriate number of shares to apply in market capitalisation calculations. When subsidiaries or share trusts hold company treasury shares as a result of repurchases or trust consolidation, there are two closing balances of shares to choose from: one in respect of the company and one in respect of the group (company shares consolidated with subsidiary and share trusts). As EPS is based upon the weighted average number of the shares of the group (SAICA, 2007: IAS 33), it is the opinion of the authors that the consistency principle should apply whereby the group number of shares should also be used as a basis for calculating market capitalisation.

The authors compared the market capitalisation published in the annual reports of the companies (i.e. closing price multiplied by published number of shares) with the group market capitalisation (i.e. closing price multiplied by group number of shares). Research results show that the majority (74,6\%) of companies publishing market capitalisation and involved in share repurchase activities (either by the company or through subsidiaries and trusts) does not use the number of group shares to calculate market capitalisation. It seems that the indiscriminate use of the term "shares in issue" without supplying a proper definition is the main cause of confusion. Some companies such as Shoprite and Foschini, to name two, aptly distinguish between the number of shares of the company and of the group, but a significant number of companies (more than half of companies considered for the sample) avoided this grey area and did not publish market capitalisation at all. While the presentation of repurchase activities (especially those by subsidiaries) and consolidation of share trusts have improved remarkably over recent years, companies and auditors are encouraged to improve reporting on market capitalisation by properly defining the number of shares used in all financial ratios. The authors of this article 
recommend that the use of the term "shares in issue" be discontinued in favour of two separate terms: "closing balance of shares: company" and "closing balance of shares: group”.

Currently there is no national accounting standard (or interpretation or circular) dealing with the calculation and presentation of market capitalisation. It is suggested that accounting standardisation be adopted in order to assist the users and presenters of financial statements with the calculation of market capitalisation. The fact that South African legislation differs from certain international legislation in respect of the treatment of treasury shares highlights the need for accounting guidance on defining the terms "shares in issue" and "treasury shares" in a South African context. Standardisation will simplify the calculation of the number of shares to be used when determining market capitalisation, i.e. the number of shares of the company, less treasury shares.

Future studies will research the efficiency/inefficiency of share repurchases (including buy-and-hold simulation) as well as the economic reasons for share repurchases (including, among others, net asset value per share compared to share price to establish over- and under-priced companies).

\section{Footnote}

The authors thank the anonymous peer reviewer who provided copious notes with constructive suggestions and criticism.

\section{References}

Bhana, D. 2006. 'The company law implications of conferring a power on a subsidiary to acquire the shares of its holding company'. Stellenbosch Law Review, 17(2):232250.

Bhana, N. 2007. 'The market reaction to open market share repurchases announcement: The South African experience', Investment Analysts Journal, 65:25-36.

Butler, D. 1999. “n Maatskappy se nuwe statutêre bevoegdheid om sy eie aandele te verkry: 'n Vertrekpunt', Stellenbosch Law Review, 10(3):284-302.

Cassim, F.H.I. 2003. 'The repurchase by a company of its own shares: The concept of treasury shares', Stellenbosch Law Review, 120(1):137-152.

Daly, K.J. 2002. 'Share returns of companies announcing share repurchases under a general authority’, Unpublished MBA research report. Johannesburg: University of the Witwatersrand.

Delport, P.A. 2001. 'Company groups and the acquisition of shares', South African Mercantile Law Journal, 13(1):121128.

JSE. 2007. JSE listing requirements. Service Issue No 3. Johannesburg: LexisNexis Butterworths. [online] URL: http://www.jse.co.za/listing_requirements.jsp. Accessed 10 April 2008.

JSE. 2004. Treatment of Share Incentive Scheme Trusts. 16 February.

Loubser, A. 2000. 'Recent developments in corporate law: Part 1', South African Mercantile Law Journal, 12(1):1-12.

Luiz, S. 2000. 'Recent developments in corporate law: Part 2', South African Mercantile Law Journal, 12(2):13-24.

RSA (Republic of South Africa). 1962 The Income Tax Act, no. 58 of 1962. Pretoria: Government Printer.

RSA (Republic of South Africa). 1973. The Companies Act, no. 61 of 1973. Pretoria: Government Printer.

RSA (Republic of South Africa). 1999. The Companies Amendment Act, no. 37 of 1999. Pretoria: Government Printer.

SAICA (South African Institute of Chartered Accountants), GAAP Monitoring Panel. 2004. 'Treatment of company share trusts in consolidated group financial statements', [online] URL:

https://www.saica.co.za/documents/TREATMENT_SHARE TRUST_FS.pdf. Accessed 10 April 2008.

SAICA (South African Institute of Chartered Accountants). 2004. ISA 720 Other information in documents containing audited financial statements. Issued: December.

SAICA (South African Institute of Chartered Accountants). 2007. CC 07/02 Headline earnings. Updated: January.

SAICA (South African Institute of Chartered Accountants). 2007. IAS 27 (AC 132) Consolidated and Separate Financial Statements. Updated: January.

SAICA (South African Institute of Chartered Accountants). 2007. IAS 32 (AC 125) Financial Instruments: Presentation. Updated: January.

SAICA (South African Institute of Chartered Accountants). 2007. IAS 33 (AC 104) Earnings per Share. Updated: January.

SAICA (South African Institute of Chartered Accountants). 2007. SIC-12 Consolidation - Special Purpose Entities. Updated: January.

UK (United Kingdom). 2005. Statutory Instrument 2003 No. 1116: The Companies (Acquisition of Own Shares)(Treasury Shares) Regulations 2003. [online] URL: http://www.opsi.gov.uk/si/si2003/20031116.htm. Accessed 10 April 2008.

Wainer, H. 2004. 'Consolidation of share incentive truststouching a nerve’, Accountancy SA, July, 12-13. 
Werksmans Attorneys. 2004. Some tax problems with treasury shares'. [online] URL: http://www.saica.co.za/integritax/1195_Some_tax_problems _with_Treasury_Shares htm. Accessed 10 April 2008. 